\title{
EEA and Norway Grants - reducing social and economic disparities in Europe
}

\author{
Leif Edvard Aarø \\ Norwegian Institute of Public Health, Bergen, Norway
}

ADDRESS FOR CORRESPONDENCE: Leif Edvard Aarø, Ph.D., Director, Department of Health Promotion, Norwegian Institute of Public Health, P.O. Box 973, Sentrum, NO-5808 Bergen, Norway, e-mail: leea@fhi.no

Iceland, Liechtenstein and Norway are three European countries that are not members of the European Union. These countries are, however, partners with the EU through the Agreement on the European Economic Area (EEA). This enables the free movement of goods, services, people and capital in an internal market, which includes all 28 member states of the European Union as well as the three countries associated through the EEA.

The EEA Agreement not only defines a large internal market, but also aims at reducing social and economic disparities in Europe. Ever since the agreement entered into force in 1994, Iceland, Liechtenstein and Norway have contributed to social and economic progress in the less wealthy member countries of the European Union.

Since 2004, the contributions have been channelled through the "EEA and Norway Grants" (2004-2009 and 2009-2014) [1]. Norway is the main contributor to both mechanisms.

In the agreements for the period 2009-2014, strengthening of bilateral relations between the donor and the beneficiary countries (16 EU countries in Central and Southern Europe and the Baltics) was introduced as an overall objective in addition to reducing social and economic disparities. The total budget for the 20092014 period was $€ 1.798$ billion. When a funding period expires, the donor countries and the EU assess the need for continued support and negotiate on the financial contributions for the next five-year period.

For the period 2009-2014, the Norway grants have been available to the 13 member countries that joined the European Union in 2004, 2007, and 2013. The EEA Grants have been available to the same countries as well as to Portugal, Spain and Greece.

Lithuania received $€ 84$ million for the last five-year period [2]. "Public health initiatives" was one of the areas that was prioritized [3]. One of the projects that received support was 'Development of a Model for the Strengthening of the Capacities to Identify and Reduce Health Inequalities. Project promoter was Lithuanian University of Health Sciences. The project was carried out in close collaboration with three partner institutions: Klaipéda University, Vilnius University and Institute of Hygiene. The project was carried out 2014-2016. The purpose was to develop a platform for monitoring of health and health care inequalities and to strengthen relevant administrative capacities of policy-making personnel at the central level as well as at the municipal level.

In this issue of Journal of Health Inequalities Stankunas and associates describe some aspects and activities related to this project [4]. Health inequalities are a major challenge for public health in Lithuania. This is a common problem across several most of the "countries in transition" [5]. Through this project the research team has succeeded in (i) describing the present situation with regard to monitoring and reducing health inequalities in Lithuania, (ii) developing a sustainable health inequalities monitoring system, (iii) developing recommendations for health professionals' contributions to reducing inequalities, and (iv) contributing to relevant capacity development for health professionals and health policy makers.

We would like to encourage submission to Journal of Health Inequalities of more reports like this one from public health initiatives under EEA and Norway Grants. We are familiar with a number of public health projects taking place in countries like Bulgaria, Czech Republic, Estonia, Hungary, Poland, Portugal, and Romania. EEA and Norway Grants may turn out to be of great importance for the development of innovative and evidence-based public health action in a number of EU member states. 


\section{DISCLOSURES}

Author reports no conflict of interest.

\section{References}

1. Available from: http://eeagrants.org/ (accessed: 27 April 2017).

2. Available from: http://eeagrants.org/Where-we-work/Lithuania (accessed: 27 April 2017).

3. EEA and Norway Grants. Lithuania factsheet. Brussels: EEA and Norway Grants 2015. Available from: http://eeagrants. org/Results-data/Documents/Publications/Factsheets/Country-factsheets (accessed: 27 April 2017).

4. Stakunas M, Kalediene R, Valinteliene R, et al. Norwegian support for tackling health inequalities in Lithuania: the process, pitfalls and results. J Health Inequal 2017; 3: 5-10.

5. Mackenbach JP, Stirbu I, Roskam AJR, et al. Socioeconomic inequalities in health in 22 European countries. N Engl J Med 2008; 358: 2468-2481 